\title{
STRUCTURAL DOMAIN OF LEARNING AND TEACHING STRATEGIES IN THE ACADEMIC PERFORMANCE OF STUDENTS
}

\author{
Leovigildo Lito D. Mallillin ${ }^{1 i}$, \\ Johdel C. Cabaluna², \\ Regilito D. Laurel', \\ Pilipinas America C. Arroyo ${ }^{4}$, \\ Teodoro M. Señoron Jr' \\ Jocelyn B. Mallillin 6 \\ ${ }^{1} \mathrm{PhD}$, Consultant and Research Specialist, \\ Quezon City, Philippines \\ ${ }^{2} \mathrm{RN}, \mathrm{DrPH}$, Assistant Professor, \\ Adamson University, \\ Manila, Philippines \\ ${ }^{3} \mathrm{PhD}$, Faculty of Education, \\ English Department, \\ University of Benghazi, \\ Libya \\ ${ }^{4}$ Lecturer, University of Tripoli, \\ Tripoli, Libya \\ 5Lecturer, University of Tripoli, \\ Tripoli, Libya \\ ${ }^{6} \mathrm{LPT}$, Master Teacher 1, \\ San Bartolome High School, \\ Quezon City, Philippines
}

\begin{abstract}
:
The study aims to describe the profile of the respondents in terms of age, gender, educational attainment, and number of years in teaching and to understand the structural domain of learning among the students in their academic performance in the area of cognitive domain of learning, affective domain of learning, and psychomotor domain of learning to include the approach on the teaching strategies of the students in their school achievement along the area of analysis and comprehension level, attitude towards the lesson, and academic performance. The quantitative research design is utilized in the study because it attempts to quantify and collect the statistical analysis on the various measures set in the research questions in the study. The purposive sampling technique is utilized in the study. This type of sampling is non-probability which is very effective in the domain of learning and expert knowledge on the needs of the study. The study comprised thirty (30) respondents only. Results show that structural cognitive domain of
\end{abstract}

${ }^{i}$ Correspondence: email loviedsunbright 0722@yahoo.com.ph 
learning reveals the ability to construct meaning from their lesson as to function and activities in their module, structural affective domain of learning reveals that students have the active attention and proper motivation to learn, willingness to respond, and feeling of satisfaction, and students have the attitude of worth, beliefs, acceptance, preference, and commitment to values, and structural psychomotor domain of learning reveals that students can express their learning through gestures, posture, facial expression, and/or creative movement. On the other hand, approach to teaching strategies as to comprehension and analysis levels shows innovation, creativity, competition, and have the ability to present concepts in their outline lesson, approach to teaching strategies as to the attitude of students toward the lesson shows that students display strict compliance toward their lessons and activities, and approach to teaching strategies as to academic performance shows that students focus on their lessons and provides output in the learning process, and students pay close attention to the direction in their lesson set up by. Findings of the study show that there is no significant agreement between the structural domain of learning among the students in their academic performance and the approach on the teaching strategies of the students in their school achievement among the respondents.

Keywords: structural domain of learning, teaching strategies, academic performance, cognitive domain of learning, affective domain of learning, and psychomotor domain of learning

\section{Introduction}

The focus in the educational system at present is based on the student as the center of learning where the curriculum is formed on the needs of the learning process. It provides a concept and understanding on the students' space that helps in the intervention and in the learning process. It is the learning and teaching process that will innovate the technologies in teaching, analyze, and support the characteristics in the contemporary profile of students in their way, and in their learning process where it evaluates and describes the system in the educational setting for student to design from the various educational institutions. It determines the advantages and disadvantages on the trends in teaching and learning process. It also provides a role in the advance technology of learning environment to provide quality of education process and satisfaction. It provides a high motivational level in the phases of the students in the focus of the educational system (Sanchez-Sepulveda, et al., 2020). In addition, to the focused system in education provides a techniques among lecturers as perceived change in the educational system and setting that will reform a better structure especially on the various domains of learning and various teaching techniques that help in the improved academic and performance of students in their achievement toward learning where it develops and extends the techniques among the teachers in the focus of the educational 
system as applied to the procedures in the learning process and academic performance and achievement of students. The process will define and consist of the conduct of the problems and in the educational system and setting in analyzing the issues for change and better improvement of the institutional system and reform in the future generation and learning process as to the content, attitude, expression, feeling, and reform consequences of students. It is a school system that provides standards and accountability to improve discourses where it explores the system in the educational setting in managing the focus in the learning environment that builds and attempts to improve the educational system and instruction in the school core of advance technology. It also provides system and policy in the interpretation of the cues and uses of educational support in the classroom setting efforts, and influences (Spillane, Seelig, Blaushild, Cohen, \& Peurach, 2019).

On the other hand, the structural domain of learning is important to consider in students' academic performance because it guides the learning process of the achievement and class performance. It is designed in various activities where the learning process will explore the knowledge of students in their in-depth activities in their subject learning especially on the academic performance and achievement as to the domain of learning is concerned. It assists the lecturers in their ways and styles in their teaching process and needs of the students. The structure of the domain of learning examines the various activities in the academic achievement and performance of the learners as to psychomotor, affective, and cognitive learning where it explores the academic performance of the learners and achievement of students and learning skills. Structural domains of learning reveal to carry the ability of the lesson through implementation and execution in the active attention of the students in their learning and motivation on their study habits willing to respond on the worth and attitude, commitment, preference, acceptance, and beliefs in the affective learning and values. Learners are exploring their visuals, body movement, coordination, touch, and auditory that will take the necessary information and ability to learn in the psychomotor learning and environment. The academic performance and the structure of the domain of learning have the extent to acquire the knowledge and skills in the learning process and in their academic performance (Mallillin, 2020). On the other hand, the structure of the domains of learning has to do with the development of the competency based-learning of the students to have a better learning process and quality of education. It is the intensity in the global educational setting that will nurture continuously the modality of teaching that will highlight the competency in the practice of education. It is a competency based-learning that depicts the various domains of learning which is imperative on the initiative that establishes the capability of such things. It embraces the engrained and needs curriculum opportunities in the design of the learning that utilizes the trends in the teaching innovation and in the learning approaches to teaching on the development and context of competency based-learning and domain of learning. It is focused on the programs on 
the benefits of the student learners as a center to the process of education and development (Mallillin, 2021).

Moreover, the academic performance of students relies on the various trends of teaching and strategies through the different domains of learning. The teachers' integration knowledge on the various techniques and strategies will enhance the learners that will provide a better interaction through the best strategies and learning process. It identifies and examines the various methods, trends, strategies, and techniques in teaching from the student perspective and learning. It provides a teaching strategy that lays the foundation of the learning process on how and why on the conduct of the classroom lesson that will assist the learners to set their expectations in the class culture for the learners to take class participation and responsibility on the various trends of teaching that directs the structure of the lecturers' instructions in terms direct activities, and techniques in teaching in the various learning process and stage in acquiring the knowledge of the learners in a complex approach and pedagogy in the technology of education that pushes on the academic concept in the learning experience and practice to assist the students on their lesson that will inspire them to achieve their goals in academics (Mallillin, et al., 2021). Hence, it features and explores the trend in scientific practices on the teaching techniques as to the inquiry of teaching and emphasizes on both the framework and theory, incorporates teaching techniques, and strategies in professional development inquiry of teaching, and selection of the subject matter that is based on the needs of the learners. The goals of the trends in the strategies in teaching and usages include the various domains of learning that focus on the teacher-centered and student-centered strategies (Halawa, et al. 2020).

Furthermore, the academic performance of the students depends on the structural domain of learning and strategies of teaching that focuses on the learners' achievement through the competency of the lectures in terms of their dedication in bringing the knowledge of learning among the students. This measures the competency of lecturers in bringing their skills to the learners since it is their profession as the noblest among all. It involves challenges on the part of the lecturers on their innovation and technical skills in terms of planning in their teaching strategies and techniques based on the various domains of learning through action (Mallillin, \& Mallillin, 2019). It has an impact on the practice and instruction among the lecturers on the academic performance of the students. The management of the instructional practices on the domains of learning and teaching strategies will generate the increased academic performance of the learners in terms of planning and teaching assessment (Francisco, \& Celon, 2020).

\section{Research Questions}

1. How may the profile of the respondents be described in terms of
a) age,
b) gender, 

c) educational attainment, and
d) number of years in teaching?

2. What is the structural domain of learning among the students in their academic performance in the area of
a) cognitive domain of learning,
b) affective domain of learning, and
c) psychomotor domain of learning?

3. What is the approach on the teaching strategies of the students in their school achievement along the area of
a) analysis and comprehension level,
b) attitude towards the lesson, and
c) academic performance?

4. Is there a significant agreement between the structural domain of learning among the students in their academic performance and the approach to the teaching strategies of the students in their school achievement among the respondents?

\subsection{Hypothesis}

There is no significant agreement between the structural domain of learning among the students in their academic performance and the approach on the teaching strategies of the students in their school achievement among the respondents.

\section{Research Design}

The quantitative research design is utilized in the study because it attempts to quantify and collect the statistical analysis on the various measures set in the research questions as to the profile of the respondents in terms of age, gender, educational attainment, and a number of years in teaching to include the structural domain of learning among the students in their academic performance in the area of the cognitive domain of learning, the affective domain of learning, and psychomotor domain of learning in addition to the approach of the teaching strategies of the students in their school achievement along the area of analysis and comprehension level, attitude towards the lesson, and academic performance of students. Therefore, the quantitative research design is conclusive and considered to be used in the specific test to describe the function and characteristics and the research accuracy problem of the questions. It is a framework and theoretically rooted in considering quantitative research. It ensures understanding the key features of the research in a required quantitative analysis in the practice and improved quantitative adapt methods (Bauer, et al., 2021). 


\subsection{Sampling Techniques}

The purposive sampling technique is utilized in the study. This type of sampling is nonprobability which is very effective in the domain of learning and expert knowledge on the needs of the study. It can be used particularly on quantitative techniques in research. It reviews the strengths and weaknesses of the different approaches in identifying the samples in the study which provides evidence and empirical viability in the sample of the population of the study. It is a convenience and subset sampling for the chosen subject of the respondents. Purposive sampling relies necessarily on convenience sampling untestable assumption in the sampling-based method and probability in an appropriate way in obtaining the number of respondents to validate the group samples and identity. It may use and fit for the purposive sampling to design and trade the representative of the study sufficient for the sample effect in obtaining the number of respondents in the study (Klar, \& Leeper, 2019).

\subsection{Participants of the Study}

The participants of the study are experienced professional lecturers in both public and private educational institutions. They are the heads, principals, lecturers, and curriculum designers who implement the structural domain of learning and teaching strategies in the academic performance of students. The study comprised thirty (30) respondents only. It is conducted for the period 2020-2021.

\subsection{Instruments Used}

A. Cognitive domain of learning

\begin{tabular}{|l|l|l|}
\hline Scale & Descriptive level & Descriptive Interpretation \\
\hline $4.20-5.00$ & Strongly Agree & Cognitive domain of learning is highly observed \\
\hline $3.40-4.19$ & Agree & Cognitive domain of learning is observed \\
\hline $2.60-3.39$ & Moderately Agree & Cognitive domain of learning is limited \\
\hline $1.80-2.59$ & Disagree & Cognitive domain of learning is not observed \\
\hline $1.00-1.79$ & Strongly Disagree & Cognitive domain of learning is not observed at all \\
\hline
\end{tabular}

B. Affective domain of learning

\begin{tabular}{|l|l|l|}
\hline Scale & Descriptive level & Descriptive Interpretation \\
\hline $4.20-5.00$ & Strongly Agree & Affective domain of learning is highly observed \\
\hline $3.40-4.19$ & Agree & Affective domain of learning is observed \\
\hline $2.60-3.39$ & Moderately Agree & Affective domain of learning is limited \\
\hline $1.80-2.59$ & Disagree & Affective domain of learning is not observed \\
\hline $1.00-1.79$ & Strongly Disagree & Affective domain of learning is not observed at all \\
\hline
\end{tabular}




\section{Psychomotor domain of learning}

\begin{tabular}{|l|l|l|}
\hline Scale & Descriptive level & Descriptive Interpretation \\
\hline $4.20-5.00$ & Strongly Agree & Psychomotor domain of learning is highly observed \\
\hline $3.40-4.19$ & Agree & Psychomotor domain of learning is observed \\
\hline $2.60-3.39$ & Moderately Agree & Psychomotor domain of learning is limited \\
\hline $1.80-2.59$ & Disagree & Psychomotor domain of learning is not observed \\
\hline $1.00-1.79$ & Strongly Disagree & Psychomotor domain of learning is not observed at all \\
\hline
\end{tabular}

D. Analysis and Comprehension level

\begin{tabular}{|l|l|l|}
\hline Scale & Descriptive level & Descriptive Interpretation \\
\hline $4.20-5.00$ & Strongly Agree & Analysis \& comprehension level is highly observed \\
\hline $3.40-4.19$ & Agree & Analysis \& comprehension level is observed \\
\hline $2.60-3.39$ & Moderately Agree & Analysis \& comprehension level is limited \\
\hline $1.80-2.59$ & Disagree & Analysis \& comprehension level is not observed \\
\hline $1.00-1.79$ & Strongly Disagree & Analysis \& comprehension level is not observed at all \\
\hline
\end{tabular}

\section{E. Attitude of Student Toward the Lesson}

\begin{tabular}{|l|l|l|}
\hline Scale & Descriptive level & Descriptive Interpretation \\
\hline $4.20-5.00$ & Strongly Agree & Attitude toward the lesson is highly observed \\
\hline $3.40-4.19$ & Agree & Attitude toward the lesson is observed \\
\hline $2.60-3.39$ & Moderately Agree & Attitude toward the lesson is limited \\
\hline $1.80-2.59$ & Disagree & Attitude toward the lesson is not observed \\
\hline $1.00-1.79$ & Strongly Disagree & Attitude toward the lesson is not observed at all \\
\hline
\end{tabular}

\section{F. Academic Performance}

\begin{tabular}{|l|l|l|}
\hline Scale & Descriptive level & Descriptive Interpretation \\
\hline $4.20-5.00$ & Strongly Agree & Academic performance is highly observed \\
\hline $3.40-4.19$ & Agree & Academic performance is observed \\
\hline $2.60-3.39$ & Moderately Agree & Academic performance is limited \\
\hline $1.80-2.59$ & Disagree & Academic performance is not observed \\
\hline $1.00-1.79$ & Strongly Disagree & Academic performance is not observed at all \\
\hline
\end{tabular}

\section{Result}

\subsection{On the Profile of the Respondents}

Table 1 presents the frequency and percentage distribution on the profile of the respondents. 


\begin{tabular}{|l|c|c|}
\hline \multicolumn{3}{|c}{ Table 1: Profile of Respondents } \\
\hline Profile: & Frequency & Percentage \\
\hline Age: & & \\
- 25 below & 7 & 23.33 \\
- 26-28 & 9 & 30.00 \\
- $29-31$ & 5 & 16.67 \\
- 32-34 & 5 & 16.67 \\
\hline Gender: & 4 & 13.33 \\
- Male & & \\
- Female & 12 & 40 \\
\hline Educational Attainment: & 18 & 60 \\
- College Graduate & & \\
- With MA Units & 5 & 16.67 \\
- WA graduate & 5 & 16.67 \\
- Doctorate Graduate & 8 & 26.67 \\
\hline Number of Years in Teaching: & 1 & 3.33 \\
- 1 year and below & 4 & 86.67 \\
- 2 - 4 years & & \\
- 5 - 7 years & 1 & 3.33 \\
- 10 years & 4 & 13.33 \\
\hline
\end{tabular}

It is noted in the table that most of the respondents belong to the age bracket 26-28 years old, with a frequency of 9 or $30 \%$ among the respondents, female respondents got a frequency of 18 or $60 \%$ among the respondents, educational attainment of the respondents are Masters of Arts graduate, with a frequency of 8 or $26.67 \%$ among the respondents, and a number of years in teaching is 10 years and above, with a frequency of 10 or $33.33 \%$ among the respondents.

\subsection{On the structural domain of learning among the respondents}

Table 2: Cognitive Domain of Learning

\begin{tabular}{|l|c|c|c|}
\hline Cognitive Domain of Learning & WM & I & $\mathbf{R}$ \\
\hline $\begin{array}{l}\text { 1. Recognition and recalling knowledge from memory based on their lesson and } \\
\text { activity. }\end{array}$ & 3.38 & MA & 5 \\
\hline $\begin{array}{l}\text { 2. Ability to construct meaning from their lesson as to function and activities in } \\
\text { their module. }\end{array}$ & 4.28 & SA & 1 \\
\hline $\begin{array}{l}\text { 3. Ability to carry out lessons through execution and } \\
\text { implementation in their lesson. }\end{array}$ & 4.12 & A & 2.5 \\
\hline $\begin{array}{l}\text { 4. Ability to determine lesson through concept, structure and } \\
\text { purposes from their outline lesson. }\end{array}$ & 4.12 & A & 2.5 \\
\hline $\begin{array}{l}\text { 5. Ability to judge the lesson based on the criteria and standards in their module } \\
\text { lesson. }\end{array}$ & 4.00 & $\mathrm{~A}$ & 4 \\
\hline Average Weighted Mean & $\mathbf{3 . 9 8}$ & $\mathbf{A}$ & \\
\hline Standard Deviation & $\mathbf{0 . 3 5 0}$ & & \\
\hline
\end{tabular}


Table 2 presents the weighted mean and the corresponding interpretation on the structural domain of learning as to the cognitive domain of learning.

It is noted in the table that rank 1 is "Ability to construct meaning from their lesson as to function and activities in their module", with a weighted mean of 4.28 or Strongly Agree which means that the cognitive domain of learning is highly observed. Rank 2 is shared by the two indicators which are "Ability to carry out lessons through execution and implementation in their lesson", and "Ability to determine lesson through concept, structure, and purposes from their outline lesson", with a weighted mean of 4.12 or Agree which means that cognitive domain of learning is observed. Rank 3 is "Ability to judge the lesson based on the criteria and standards in their module lesson", with a weighted mean of 4.00 or Agree which means that cognitive domain of learning is observed. The least in rank is "Recognition and recalling knowledge from memory based on their lesson and activity", with a weighted mean of 3.38 or Moderately Agree, which means the cognitive domain of learning is limited. The overall average weighted mean is 3.98 or Agree which means that the cognitive domain of learning in this area is observed.

Table 3: Affective Domain of Learning

\begin{tabular}{|l|c|c|c|}
\hline Affective Domain of Learning & WM & I & $\mathbf{R}$ \\
\hline $\begin{array}{l}\text { 1. Students have the sense of learning, the existence of response, awareness } \\
\text { and willingness. }\end{array}$ & 4.14 & A & 3 \\
\hline $\begin{array}{l}\text { 2. Students have the active attention and proper motivation to learn, } \\
\text { willingness to respond, and feeling of satisfaction. }\end{array}$ & 4.22 & SA & 1.5 \\
\hline $\begin{array}{l}\text { 3. Students have the attitude of worth, beliefs, acceptance, preference, and } \\
\text { commitment to values. }\end{array}$ & 4.22 & SA & 1.5 \\
\hline $\begin{array}{l}\text { 4. Students internalize values and beliefs according to priority in their lesson } \\
\text { and learning activities. }\end{array}$ & 3.30 & MA & 5 \\
\hline $\begin{array}{l}\text { 5. Students can relate behavior that reflects a set of values in life, practicing, } \\
\text { and acting on their values and beliefs. }\end{array}$ & 3.36 & MA & 4 \\
\hline Average Weighted Mean & 3.85 & A & \\
\hline Standard Deviation & $\mathbf{0 . 4 7 4}$ & & \\
\hline
\end{tabular}

Table 3 presents the weighted mean and the corresponding interpretation on the structural domains of learning as to the affective domain of learning.

As shown on the table, rank 1 is shared by the two indicators which are "Students have the active attention and proper motivation to learn, willingness to respond, and feeling of satisfaction", and "Students have the attitude of worth, beliefs, acceptance, preference, and commitment to values", with a weighted mean of 4.22 or Strongly Agree which means that affective domain of learning is highly observed. Rank 2 is "Students have the sense of learning, the existence of response, awareness, and willingness", with a weighted mean of 4.14 Agree which means that affective domain of learning is observed, Rank 3 is "Students can relate behavior that reflects a set of values in life, practicing, and acting on their values and beliefs", with a weighted mean of 3.36 or Moderately Agree which means that affective domain of learning is limited. The least in 
rank is "Students internalize values and beliefs according to priority in their lesson and learning activities", with a weighted mean of 3.30 or Moderately Agree which means that the affective domain of learning is limited. The overall average weighted mean is 3.85 or Agree which means that the affective domain of learning in this area is observed.

Table 4: Psychomotor Domain of Learning

\begin{tabular}{|l|c|c|c|}
\hline Psychomotor Domain of Learning & WM & I & R \\
\hline $\begin{array}{l}\text { 1. Students can encode information and activities in expressing and interpreting } \\
\text { information or concepts. }\end{array}$ & 3.17 & MA & 5 \\
\hline $\begin{array}{l}\text { 2. Students can express their learning through gestures, posture, facial } \\
\text { expression, and/or creative movement. }\end{array}$ & 4.24 & SA & 1 \\
\hline $\begin{array}{l}\text { 3. Students can relate to endurance, flexibility, agility, strength, reaction-response } \\
\text { time. }\end{array}$ & 4.04 & A & 3.5 \\
\hline $\begin{array}{l}\text { 4. Students can relate to body movement, visuals, auditory, touch, or } \\
\text { coordination, and the ability to take information from the environment and react. }\end{array}$ & 4.10 & A & 2 \\
\hline $\begin{array}{l}\text { 5. Students have the skills related to complex actions like walking, running, } \\
\text { jumping, pulling, pushing, and manipulation based on their lesson. }\end{array}$ & 4.01 & $\mathrm{~A}$ & 3.5 \\
\hline Average Weighted Mean & $\mathbf{3 . 9 1}$ & $\mathbf{A}$ & \\
\hline Standard Deviation & $\mathbf{0 . 4 2 4}$ & & \\
\hline
\end{tabular}

Table 4 presents the weighted mean and the corresponding interpretation on the structural domain of learning as to the psychomotor domain of learning.

As observed in the table, rank 1 is "Students can express their learning through gestures, posture, facial expression, and/or creative movement", with a weighted mean of 4.24 or Strongly Agree which means that the psychomotor domain of learning is highly observed. Rank 2 is "Students can relate to body movement, visuals, auditory, touch, or coordination, and the ability to take information from the environment and react", with a weighted mean of 4.10 or Agree which means that the psychomotor domain of learning is observed. Rank 3 is shared by the two indicators which are "Students can relate to endurance, flexibility, agility, strength, reaction-response time", and "Students have the skills related to complex actions like walking, running, jumping, pulling, pushing, and manipulation based on their lesson", with a weighted mean of 4.01 or Agree which means that psychomotor domain of learning is observed. The least in rank is "Students can encode information and activities in expressing and interpreting information or concepts", with a weighted mean of 3.17 or Moderately Agree which means that the psychomotor domain of learning is limited. The overall average weighted mean is 3.91 of Agree which means that the psychomotor domain of learning in this area is observed.

\subsection{On the approach to the teaching strategies among the respondents}

Table 5 presents the weighted mean and the corresponding interpretation on the approach of teaching strategies as to analysis and comprehension level of the respondents. 


\begin{tabular}{|c|c|c|c|}
\hline \multicolumn{4}{|l|}{ Table 5: Analysis and Comprehension Level } \\
\hline Analysis and Comprehension Level & WM & I & $\mathbf{R}$ \\
\hline $\begin{array}{l}\text { 1. Comprehension and analysis levels show innovation, creativity, } \\
\text { competition, and have the ability to present concepts in their outline lesson. }\end{array}$ & 4.30 & SA & 1 \\
\hline $\begin{array}{l}\text { 2. Analysis and comprehension level of students show skills in creative } \\
\text { thinking, can learn and can communicate with passion and ideas based on } \\
\text { their lesson. }\end{array}$ & 4.12 & A & 3 \\
\hline $\begin{array}{l}\text { 3. Students possess skills to define problems and design proper solutions in } \\
\text { an effective way in their analysis and comprehension level. }\end{array}$ & 4.00 & A & 4.5 \\
\hline $\begin{array}{l}\text { 4. Comprehension and analysis levels are based on their skills and needs and } \\
\text { are based on students' level of knowledge to inspire, motivate, and empower } \\
\text { them to learn and expand the mind of their lesson. }\end{array}$ & 4.18 & A & 2 \\
\hline $\begin{array}{l}\text { 5. Comprehension and analysis level acquire skills and knowledge for } \\
\text { various situations in their activities and lessons. }\end{array}$ & 4.00 & A & 4.5 \\
\hline Average Weighted Mean & 4.12 & A & \\
\hline Standard Deviation & 0.127 & & \\
\hline
\end{tabular}

As gleaned in the table, rank 1 is "Comprehension and analysis levels show innovation, creativity, competition, and have the ability to present concepts in their outline lesson", with a weighted mean of 4.30 or Strongly Agree which means that analysis and comprehension level is highly observed. Rank 2 is "Comprehension and analysis levels are based on their skills and needs and are based on students' level of knowledge to inspire, motivate, and empower them to learn and expand the mind of their lesson", with a weighted mean of 4.18 or Agree which means that analysis and comprehension level is observed. Rank 3 is "Analysis and comprehension level of students show skills in creative thinking, can learn and can communicate with passion and ideas based on their lesson", with a weighted mean of 4.12 or Agree which means that analysis and comprehension level is observed. The least in rank is shared by the two indicators which are "Students possess skills to define problems and design proper solutions in an effective way in their analysis and comprehension level", and "Comprehension and analysis level acquire skills and knowledge for various situations in their activities and lessons", with a weighted mean of 4.00 or Agree which means that analysis and comprehension level is observed. The overall average weighted mean is 4.12 or Agree which means that analysis and comprehension level are observed in this area.

Table 6: Attitude of Student Toward the Lesson

\begin{tabular}{|l|l|l|l|}
\hline Attitude of Student Toward the Lesson & WM & I & R \\
\hline $\begin{array}{l}\text { 1. Students show enthusiasm in the lesson setting up and in their learning } \\
\text { process. }\end{array}$ & 3.20 & MA & 5 \\
\hline 2. Students display strict compliance toward their lessons and activities. & 4.27 & SA & 1 \\
\hline $\begin{array}{l}\text { 3. Students submit their various activities intended for the learning process in } \\
\text { their subject and on time. }\end{array}$ & 4.10 & A & 2.5 \\
\hline $\begin{array}{l}\text { 4. Students request for assistance from their teachers for the lesson that is not } \\
\text { clearly understood by them. }\end{array}$ & 3.30 & MA & 4 \\
\hline
\end{tabular}




\begin{tabular}{|l|l|l|l|}
\hline \hline $\begin{array}{l}\text { 5. Students express freely their opinion based on their lessons and activities } \\
\text { in their subjects. }\end{array}$ & 4.10 & A & 2.5 \\
\hline Average Weighted Mean & 3.94 & A & \\
\hline Standard Deviation & $\mathbf{0 . 7 5 9}$ & & \\
\hline
\end{tabular}

Table 6 presents the weighted mean and the corresponding interpretation on the approach of teaching strategies as to the attitude of students toward the lesson among the respondents.

As acknowledged in the table, rank 1 is "Students display strict compliance toward their lessons and activities", with a weighted mean of 4.27 or Strongly Agree which means that the attitude of students toward the lesson is highly observed. Rank 2 is shared by the two indicators which are "Students submit their various activities intended for the learning process in their subject and on time", and "Students express freely their opinion based on their lessons and activities in their subjects", with a weighted mean of 4.10 or Agree which means that attitude of the student toward the lesson is observed. Rank 3 is "Students request for assistance from their teachers for the lesson that is not clearly understood by them", with a weighted mean of 3.30 or Moderately Agree which means that the attitude of students toward the lesson is limited. The least in rank is "Students show enthusiasm in the lesson setting up and in their learning process", with a weighted mean of 3.20 or Moderately Agree which means that the attitude of students toward the lesson is limited. The overall average weighted mean is 3.94 or Agree which means that the attitude of students toward the lesson is observed in this area.

Table 7: Academic Performance

\begin{tabular}{|l|c|c|c|}
\hline Academic Performance & WM & I & $\mathbf{R}$ \\
\hline 1. Students express freely their opinion and ideas in their lessons and activities. & 4.08 & A & 4 \\
\hline 2. Students focus on their lessons and provide output in the learning process. & 4.23 & SA & 1.5 \\
\hline 3. Students pay close attention to the direction in their lesson set up by. & 4.23 & SA & 1.5 \\
\hline $\begin{array}{l}\text { 4. Students develop their time management in their activities and lessons in their } \\
\text { subjects. }\end{array}$ & 4.12 & A & 3 \\
\hline $\begin{array}{l}\text { 5. Students establish academic goals to accomplish the task required in their } \\
\text { subject. }\end{array}$ & 3.00 & MA & 5 \\
\hline Average Weighted Mean & $\mathbf{3 . 9 3}$ & $\mathbf{A}$ & \\
\hline Standard Deviation & $\mathbf{0 . 5 2 5}$ & & \\
\hline
\end{tabular}

Table 7 presents the weighted mean and the corresponding interpretation on the approach of teaching strategies as to the academic performance of the respondents.

As observed in the table, rank 1 is shared by the two indicators which are "Students focus on their lessons and provide output in the learning process", and "Students pay close attention to the direction in their lesson set up by", with a weighted mean of 4.23 or Strongly Agree which means that academic performance is highly observed. Rank 2 is "Students develop their time management in their activities and lessons in their subjects", with a weighted mean of 4.12 or Agree which means that 
academic performance is observed. Rank 3 is "Students express freely their opinion and ideas in their lessons and activities", with a weighted mean of 4.08 or Agree which means that academic performance is observed. The least in rank is "Students establish academic goals to accomplish the task required in their subject", with a weighted mean of 3.00 or Moderately Agree which means that academic performance is limited. The overall average weighted mean is 3.93 or Agree which means that academic performance is observed in this area.

4.4 On the significant agreement between the structural domains of learning and approach to teaching strategies of the students in their school achievement among the respondents

Table 8: Test of Significant Agreement Between Structural Domain of Learning and Approach to Teaching Strategies Among the Respondents

\begin{tabular}{|c|c|c|c|}
\hline Variables & $\begin{array}{l}\text { t-computed } \\
\text { value }\end{array}$ & $\begin{array}{l}\text { Relationships } \\
\text { *significant } \\
\text { *not significant }\end{array}$ & $\begin{array}{l}\text { Hypotheses } \\
\text { *accepted } \\
\text { *rejected }\end{array}$ \\
\hline $\begin{array}{l}\text { a. cognitive domain of learning } \\
\text { - } \quad \text { analysis and comprehension level } \\
\text { - } \quad \text { attitude towards the lesson } \\
\text { - } \quad \text { academic performance }\end{array}$ & $\begin{array}{l}-1.22551 \\
0.19399 \\
0.26939\end{array}$ & $\begin{array}{l}\text { not significant } \\
\text { not significant } \\
\text { not significant }\end{array}$ & $\begin{array}{l}\text { accepted } \\
\text { accepted } \\
\text { accepted }\end{array}$ \\
\hline $\begin{array}{l}\text { b. affective domain of learning } \\
\text { - analysis and comprehension level } \\
\text { - } \quad \text { attitude towards the lesson } \\
\text { - } \quad \text { academic performance }\end{array}$ & $\begin{array}{l}-1.86850 \\
-0.43176 \\
-0.42704\end{array}$ & $\begin{array}{l}\text { not significant } \\
\text { not significant } \\
\text { not significant }\end{array}$ & $\begin{array}{l}\text { accepted } \\
\text { accepted } \\
\text { accepted }\end{array}$ \\
\hline $\begin{array}{l}\text { c. psychomotor domain of learning } \\
\text { - analysis and comprehension level } \\
\text { - } \quad \text { attitude towards the lesson } \\
\text { - } \quad \text { academic performance }\end{array}$ & $\begin{array}{c}-1.51727 \\
-0.14686 \\
0.10948 \\
\end{array}$ & $\begin{array}{l}\text { not significant } \\
\text { not significant } \\
\text { not significant }\end{array}$ & $\begin{array}{l}\text { accepted } \\
\text { accepted } \\
\text { accepted }\end{array}$ \\
\hline
\end{tabular}

Table 8 presents the test of significant agreement between the structural domain of learning and the approach to teaching strategies among the respondents.

It reveals in the $t$ computed values that all variables fall below the $t$ critical value of 2.045, two-tailed test, $\mathrm{df}$ of 29 at 0.05 level of significance which the relationship is not significant and the decision is accepted. Therefore, it is safe to say that there is no significant agreement between the structural domain of learning among the students in their academic performance and the approach to the teaching strategies of the students in their school achievement among the respondents. 


\section{Discussion}

The structural domain of learning and teaching strategies in the academic performance provides a positive outcome for both lecturers and students since learning is a two-way process in the educational system. The profile of the respondents shows that their dedication to their teaching profession relies on their motive and interest in life. It identifies the influence of the domain of learning and the approaches to teaching strategy on the factors to the academic performance of the learners and challenges. The structural design of the learning process provides impact related to their learning process in the various domain of learning and teaching strategies so that the learning process among students will be met according to the set standard in the learning outcome of the learners. It provides learning strategies that in turn influence the learners on academic achievement and performance (Hayat, Shateri, Amini, \& Shokrpour, 2020).

Hence, the structural cognitive domain of learning shows the ability to construct meaning from their lesson as to function and activities in their module that will describe the interaction pattern and complexity for both students and teachers. It enhances the learning process and assessment of students and understanding to improve the classroom setting and perspective in the domains of learning and teaching strategies (Eriksson, Boistrup, \& Thornberg, 2020). It also shows that there is an ability to carry out lessons through execution and implementation in their lesson, and ability to determine lesson through concept, structure, and purpose from the outlined lesson where it enhances the knowledge and integration of the technology of teaching that focuses on the learning of students (Mallillin, Carag, Mallillin, \& Laurel, 2020). In addition, it shows the ability to judge the lesson based on the criteria and standards in their module lesson where a teacher is guided on the context of the lesson based on the needs of the students especially now that the teaching process has shifted to blended learning. It provides the process of learning and instructional design that depicts on the structure of the domain of learning and teaching strategies based on the standard instructional material in a constructive way and alignment to improve the learning process of students (Cahapay, 2021). Lastly, it shows that there is a recognition and recalling knowledge from memory based on their lesson and activity where it describes the pedagogical experiences of subjects on the analysis of the objectives and goals in a substantial and creative work of the students to improve the quality of teaching and desired effect on the pedagogy of the educational system in creative learning (Hamroev, 2019).

Moreover, on the structural affective domain of learning, it shows that students have the active attention and proper motivation to learn, willingness to respond, and feeling of satisfaction, and students have the attitude of worth, beliefs, acceptance, preference, and commitment to values where it provides a vision and attitude of both the learners and teachers to analyze the process of learning and framework in accordance to the affective domain of learning for students to apply the principles in life. It implements and identifies the teaching delivery mode, support among the learners, and process in 
the school system to boost the potential of students and to ensure the quality of education, (Mallillin, et. al., 2020). On the other hand, it shows also that students have the sense of learning, the existence of response, awareness, and willingness where it describes the learning and quality of teaching in instilling values to students and application of the lesson in a continuous sense of learning and intellect to the characteristics and development of students. This will help students to better understand the practice and improve learning engagement (Perso, \& Hayward, 2020). Constantly, it shows that students can relate behavior that reflects a set of values in life, practicing, and acting on their beliefs. This can motivate students to understand the broad framework in undermining the facilitation of their psychological wellness in the educational setting and direct relevance on the needs in the learning context and practices to support the learning process (Ryan, \& Deci, 2020). It shows that students internalize values and beliefs according to priority in their lesson and learning activities where it implements the values to strengthen the students and their characters in their lesson, balance the practice and understanding, recognize the differences and respect, and deals with accustomed students (Subaidi, 2020).

Furthermore, the structural psychomotor domain of learning shows that students can express their learning through gestures, posture, facial expression, and/or creative movement. This involves learning and a substantial amount of psychomotor domain in understanding and recognizing the learning context as key intervention and design in addressing the individual needs of the learners in exploring the verbal and non-verbal gestures via facial expression during the learning process (Behera, et. al., 2020). It also reveals that students can relate to body movement, visuals, auditory, touch, or coordination, and the ability to take information from the environment and reaction. It provides a process of senses in the learning process of student that influences their potential and determination (Delgado-Lobete, Pértega-Díaz, Santos-del-Riego, \& Montes-Montes, 2020). In addition, it reveals that students can relate to endurance, flexibility, agility, strength, reaction-response time, and students have the skills related to complex actions like walking, running, jumping, pulling, pushing and manipulation based on their lesson where it plays an active role in the experiences of the learners as to the social, physical and mental development of the learners. It stimulates an optimal level and development on the psychomotor need that improves the flexibility and strength of the learners. It influences the strength and endurance program in the composition and adaptive body changes of students (Görner, \& Reineke, 2020). Lastly, it shows that students can encode information and activities in expressing and interpreting information or concepts. It provides critical thinking skills among the learners at their educational level. It applies procedures on the understanding of their solving concept in their learning process. It provides support and an effective method for the knowledge of the learners. This enables the learners to organize and analyze the concepts of learning, (Jonassen, \& Carr, 2020). 
Consequently, the approach of teaching strategies as to analysis and comprehension level of the respondents shows innovation, creativity, competition, and have the ability to present concepts in their outline lesson. This can help students in their learning process in a meaningful manner since they are being assisted to foster their creativity and innovation based on the domain of learning and teaching strategies set for the learning process through the creative tasks, engagement, cooperative attitude, and learning competitive value to include the behavior engagement, cognitive and emotional engagement on their creative task of learning where it strengthens the learning opportunity of the students (Hong, Chen, Wang, Ye, \& Ye, 2020). Yet, it also shows that comprehension and analysis levels are based on their skills and needs and are based on students' level of knowledge to inspire, motivate, and empower to learn and expand the mind of their lesson. It also provides comprehensive and accurate skills and development for the students. It assesses their level of learning that explores and influences the factors of their knowledge and level (Prinz, Golke, \& Wittwer, 2020). On the other hand, it shows that the analysis and comprehension level of students show skills in creative thinking, can learn, and can communicate with passion and ideas based on their lesson. It provides students with their framework and level of creative thinking in their learning process mentally in various situations where it analyzes the concept of their learning where they can express themselves to the fullest based on their lesson (Aini, Mukhlis, Annizar, Jakaria, \& Septiadi; 2020, February). Lastly, it shows that students possess skills to define problems and design proper solutions in an effective way in their analysis and comprehension level, and acquire skills and knowledge for various situations in their activities and lessons. This emphasizes that the learning process has approaches and goals to be adapted in all disciplines of learning in the improved skills of students in their learning process (Akben, 2020).

In contrast, the approach of teaching strategies as to the attitude of students toward the lesson among the respondents shows students display strict compliance toward their lessons and activities where it establishes the interaction in the classroom teaching that increases the attention of the students in the development of the classroom setting especially on the static pattern to act in the interaction of the select strategies of the lecturers that serve on the procedures and rules on the interaction and structure of the teaching strategies on the various domains of learning (Ball, 2020). It also shows that students submit their various activities intended for the learning process in their subject and on time, and students express freely their opinion based on their lessons and activities in their subjects where the application of learning will support the learning knowledge of the students which is appropriate in the studies of the learners. It features to support the learners' activities in their learning lesson using the domains of learning and teaching strategies (Simanullang, \& Rajagukguk; 2020, February). Hence, it shows that students request assistance from their teachers for the lesson that is not clearly understood by them. This is essential for students to be guided properly and improve the learning environment among them. It is a kind of assistance that is detrimental among 
the learners in creating demand and maintains assistance on their learning process, (Patikorn, \& Heffernan; 2020, August). Lastly, it shows that students are enthusiastic in the lesson setting up and in their learning process where it explores the student engagement and influences in the outcome and literacy of their learning process. It also provides a positive output on the performance of students in the achievement of their indication to the desired outcome and learning (Troy Frensley, Stern, \& Powell, 2020).

Lastly, the approach of teaching strategies as to the academic performance of the respondents shows that students are focused on their lessons and provide output in the learning process, and students pay close attention to the direction in their lesson set up by where it increases the student support on the learning skills of students that may experience the real learning process. It will support the teachers in their learning skills and process to assess the method and effectiveness in the collaborative learning of students (Niu, \& Niemi; 2020). Yet, it also shows that students develop their time management in their activities and lessons in their subjects where it analyses their methods of learning in the management of learning and context. It provides distinct time management on the learning process of students as part of their strategies and tactics in the self-regulated framework and learning on the part of the learners (Uzir, et al.; 2019, September). In addition, it shows that students express freely their opinion and ideas in their lessons and activities. It also provides an understanding of the opinion of students in their lesson through the learning technology and improvement usage in a sustainable learning process of students. It provides an updated and well-suited based trend in the technology of education facilities among the learners (Verma, Illés, Stoffová, \& Bakonyi, 2020). Lastly, it shows that students establish academic goals to accomplish the task required in their subject. It is strategic planning among the teachers as a key indicator which is very crucial from the various private and public educational institutions. It is a tool that indicates to convey the performance of students in a simple way where it provides options on the performance of the students in their academic performance (Parada, Blasco-Blasco, \& Liern, 2019).

\section{Conclusion}

1) It shows that most of the respondents belong to the age bracket 26-28 years old, female respondents dominate in number than the male respondents, it also shows that their educational attainment is a Master of Arts graduate, and 10 years and above is their teaching experiences.

2) The structural cognitive domain of learning shows the ability to construct meaning from their lesson as to function and activities in their module, the structural affective domain of learning shows that students have the active attention and proper motivation to learn, willingness to respond, and feeling of satisfaction, and students have the attitude of worth, beliefs, acceptance, preference, and commitment to values, and the structural psychomotor domain of learning shows 
that students can express their learning through gestures, posture, facial expression, and/or creative movement.

3) Approach to teaching strategies as to comprehension and analysis levels shows innovation, creativity, competition, and have the ability to present concepts in their outline lesson, approach to teaching strategies as to the attitude of students toward the lesson shows that students display strict compliance toward their lessons and activities, and approach to teaching strategies as to academic performance shows that students focus on their lessons and provides output in the learning process, and students pay close attention to the direction in their lesson set up by.

4) It shows that there is no significant agreement between the structural domain of learning among the students in their academic performance and the approach to the teaching strategies of the students in their school achievement among the respondents.

\section{Recommendations}

1) Since the profile of the respondents is in their prime age, they need to explore more on the teaching strategies especially in adapting the different domains of learning though they are master's degree graduates. They need to explore the trends in teaching to enhance the learning process among the learners and to upgrade their knowledge to the trends in the advanced technology of teaching and learning domains among the respondents.

2) There is a need to apply the principles of the cognitive domain of learning in recalling and recognizing the knowledge from based memory of the activity in the lesson and need to provide standard criteria for the outlined lesson, especially in the implementation, execution to determine the lesson through concept, purpose, and structure, there is a need to apply the structure of the affective domain of learning through internalizing the beliefs, values in prioritizing the lesson activities that can reflect and relate the behavior of the students and sense of learning, willingness, and awareness, and there is also a need to determine the structure of the psychomotor domain of learning that can enhance the information, and knowledge of activities in expressing the information, concept, interpretation, that will relate to the flexibility, endurance, reaction-response time, strength, agility, of the students in the lesson.

3) Approach to teaching strategies on analysis and comprehension level should possess skills that will define problems and design proper solutions in an effective way in acquiring skills and knowledge for various situations in the activities and lessons through creative thinking, creating learning, and creating communication with passion and ideas based on the lesson, approach to teaching strategies as to the attitude of the student toward the lesson should show enthusiasm in the set- 
up lesson in the learning process and they need to clarify some points of ideas that are vague to understand by the students, and approach to teaching strategies as to the academic performance of the students should establish and accomplish academic goals in the required task of the subject lesson that can express opinion freely and ideas of the activities of the lesson, especially on the development to time and management of the lesson and activities in the subjects.

4) Since the findings show that there is no significant agreement between the structural domain of learning among the students in their academic performance and the approach to the teaching strategies of the students in their school achievement among the respondents, there is a need to explore study not tackled in the study like the proper techniques in handling the lesson based on the needs of the respondents especially in the proper usage of the different domains of learning as to cognitive, affective, and psychomotor.

\section{Conflict of Interest Statement}

There is no conflict of interest in this research among the members of the group. This is just purely research as a contributory factor to the research field on professional education teaching pedagogy.

\section{About the Author}

Dr. Leovigildo Lito D. Mallillin is a Consultant and Research Specialist. He is a Doctor of Philosophy in Development Education, Master of Arts in Administration and Supervision, and Bachelor of Secondary Education, major in English. An International English Lecturer in Al-Fateh University, North Africa and Gulf College at Sultanate of Oman. Published several research articles in the different international journals.

Johdel C. Cabaluna is a Registered Nurse and a Licensed Professional Teacher. He is an Assistant Professor at Adamson University, Manila Philippines. He is also a reviewer and lecturer in various review centers in the Philippines.

Dr. Regilito D. Laurel is an Assistan Professor at Faculty of Education, English Department University of Benghazi, Libya. His research interests include continuing professional development curriculum innovation, TESOL, ELT, Teaching Methodology, and Action Research on Education \& ELT.

Ms. Pilipinas America Arroyo is an English Language Lecturer at the University of Tripoli, Libya and taught English to Libyan English major and medical students for eleven years. She earns her Master of English as a Second Language at the University of Philippines.

Mr. Teodoro M. Señoron Jr. is an English Lecturer at University of Tripoli. He earned his Master of Arts in English at the University of the Philippines.

Ms. Jocelyn B. Mallillin is a Master Teacher 1 and Licensed Professional Teacher. She is presently connected at San Bartolome High School in Quezon City, Philippines. 


\section{References}

Aini, A. N., Mukhlis, M., Annizar, A. M., Jakaria, M. H. D., \& Septiadi, D. D. (2020, February). Creative thinking level of visual-spatial students on geometry HOTS problems. In Journal of Physics: Conference Series (Vol. 1465, No. 1, p. 012054). IOP Publishing.

Akben, N. (2020). Effects of the problem-posing approach on students' problem solving skills and metacognitive awareness in science education. Research in Science Education, 50(3), 1143-1165.

Ball, S. (2020). Initial encounters in the classroom and the process of establishment. In Life in School (pp. 108-120). Routledge.

Bauer, G. R., Churchill, S. M., Mahendran, M., Walwyn, C., Lizotte, D., \& Villa-Rueda, A. A. (2021). Intersectionality in quantitative research: A systematic review of its emergence and applications of theory and methods. SSM-population health, 100798.

Behera, A., Matthew, P., Keidel, A., Vangorp, P., Fang, H., \& Canning, S. (2020). Associating facial expressions and upper-body gestures with learning tasks for enhancing intelligent tutoring systems. International Journal of Artificial Intelligence in Education, 30(2), 236-270.

Cahapay, M. B. (2021). How to Plan Lessons in the New Normal Education: A Reintroduction to Selected Instructional Design Processes. Aquademia, 5(1), ep21006.

Delgado-Lobete, L., Pértega-Díaz, S., Santos-del-Riego, S., \& Montes-Montes, R. (2020). Sensory processing patterns in developmental coordination disorder, attention deficit hyperactivity disorder and typical development. Research in developmental disabilities, 100, 103608.

Eriksson, E., Boistrup, L. B., \& Thornberg, R. (2020). “You must learn something during a lesson": how primary students construct meaning from teacher feedback. Educational Studies, 1-18.

Francisco, C. D. C., \& Celon, L. C. (2020). Teachers' Instructional Practices and Its Effects on Students' Academic Performance. Online Submission, 6(7), 64-71.

Görner, K., \& Reineke, A. (2020). The influence of endurance and strength training on body composition and physical fitness in female students. Journal of Physical Education and Sport, 20, 2013-2020.

Halawa, S., Hsu, Y. S., Zhang, W. X., Kuo, Y. R., \& Wu, J. Y. (2020). Features and trends of teaching strategies for scientific practices from a review of 2008-2017 articles. International Journal of Science Education, 42(7), 1183-1206.

Hamroev, A. R. (2019). Modeling activities of teachers when designing creative activities of students. European Journal of Research and Reflection in Educational Sciences, 2019. 
Hayat, A. A., Shateri, K., Amini, M., \& Shokrpour, N. (2020). Relationships between academic self-efficacy, learning-related emotions, and metacognitive learning strategies with academic performance in medical students: a structural equation model. BMC medical education, 20(1), 1-11.

Hong, J. C., Chen, M. L., Wang, C. M., Ye, J. N., \& Ye, J. H. (2020). Relationship among the urban and rural students' cooperative attitude, creative task engagements and competition value in participating a steam co-creation contest. International Journal of Information and Education Technology, 10(12), 873-881.

Jonassen, D. H., \& Carr, C. S. (2020). Mindtools: Affording multiple knowledge representations for learning. In Computers as cognitive tools, volume two: No more walls (pp. 165-196). Routledge.

Klar, S., \& Leeper, T. J. (2019). Identities and intersectionality: a case for Purposive sampling in Survey-Experimental research. Experimental Methods in Survey Research: Techniques that Combine Random Sampling with Random Assignment, 419-433.

Mallillin, et al. (2021). Strategies, Trends, Methods and Techniques of Teaching in the New Normal Learning Perspective of Students. East African Scholars J Edu Humanit Lit; Vol-4: Iss-7 (July, 2021): 265-274

Mallillin, L. L. D. (2020). Different Domains in Learning and the Academic Performance of the Students. Journal of Educational System, 4(1), 1-11.

Mallillin, L. L. D., \& Mallillin, J. B. (2019). Competency Skills and Performance Level of Faculties in the Higher Education Institutions (HEIs). European Journal of Education Studies.

Mallillin, L. L. D., Carag, E. A., Mallillin, J. B., \& Laurel, R. D. (2020). Integration of knowledge through online classes in the learning enhancement of students. European Journal of Open Education and E-learning Studies, 5(1).

Mallillin, L. L. D., Mallillin, J. B., Carag, E. A., Collado, J. B., \& Largo, M. G. D. (2020). A framework in online learning process: a guide to educational teaching during covid 19 pandemic. European Journal of Open Education and E-learning Studies, $5(2)$.

Mallillin, L. L. D. (2021). Competency Based-Learning and Quality Education in the New Normal Modality of Teaching.

Niu, S. J., \& Niemi, H. (2020). Teachers support of students' social-emotional and selfmanagement skills using a solution-focused Skillful-Class method. The European Journal of Social \& Behavioural Sciences.

Parada, S. E., Blasco-Blasco, O., \& Liern, V. (2019). Adequacy indicators based on preestablished goals: an implementation in a Colombian University. Social Indicators Research, 143(1), 1-24.

Patikorn, T., \& Heffernan, N. T. (2020, August). Effectiveness of crowdsourcing ondemand assistance from teachers in online learning platforms. In Proceedings of the Seventh ACM Conference on Learning@ Scale (pp. 115-124). 
Perso, T., \& Hayward, C. (2020). Teaching Indigenous students: Cultural awareness and classroom strategies for improving learning outcomes. Routledge.

Prinz, A., Golke, S., \& Wittwer, J. (2020). How accurately can learners discriminate their comprehension of texts? A comprehensive meta-analysis on relative metacomprehension accuracy and influencing factors. Educational Research Review, 100358.

Ryan, R. M., \& Deci, E. L. (2020). Intrinsic and extrinsic motivation from a selfdetermination theory perspective: Definitions, theory, practices, and future directions. Contemporary Educational Psychology, 61, 101860.

Sanchez-Sepulveda, M. V., Fonseca, D., García-Holgado, A., García-Peñalvo, F. J., Franquesa, J., Redondo, E., \& Moreira, F. (2020). Evaluation of an interactive educational system in urban knowledge acquisition and representation based on students' profiles. Expert Systems, 37(5), e12570.

Simanullang, N. H. S., \& Rajagukguk, J. (2020, February). Learning Management System (LMS) Based on Moodle to Improve Students Learning Activity. In Journal of Physics: Conference Series (Vol. 1462, No. 1, p. 012067). IOP Publishing.

Spillane, J. P., Seelig, J. L., Blaushild, N. L., Cohen, D. K., \& Peurach, D. J. (2019). Educational system building in a changing educational sector: Environment, organization, and the technical core. Educational Policy, 33(6), 846-881.

Subaidi, S. (2020). Strengthening Character Education in Indonesia: Implementing Values from Moderate Islam and the Pancasila. Journal of Social Studies Education Research, 11(2), 120-132.

Troy Frensley, B., Stern, M. J., \& Powell, R. B. (2020). Does student enthusiasm equal learning? The mismatch between observed and self-reported student engagement and environmental literacy outcomes in a residential setting. The Journal of Environmental Education, 51(6), 449-461.

Uzir, A., Gašević, D., Matcha, W., Jovanović, J., Pardo, A., Lim, L. A., \& Gentili, S. (2019, September). Discovering time management strategies in learning processes using process mining techniques. In European Conference on Technology Enhanced Learning (pp. 555-569). Springer, Cham.

Verma, C., Illés, Z., Stoffová, V., \& Bakonyi, V. (2020). Opinion prediction of Hungarian students for real-time e-learning systems: A futuristic sustainable technologybased solution. Sustainability, 12(16), 6321. 
Leovigildo Lito D. Mallillin, Johdel C. Cabaluna, Regilito D. Laurel,

Pilipinas America C. Arroyo, Teodoro M. Señoron Jr, Jocelyn B. Mallillin

STRUCTURAL DOMAIN OF LEARNING AND TEACHING STRATEGIES

IN THE ACADEMIC PERFORMANCE OF STUDENTS

Author(s) will retain the copyright of their published articles agreeing that a Creative Commons Attribution 4.0 International License (CC BY 4.0) terms will be applied to their work. Under the terms of this license, no permission is required from the author(s) or publisher for members of the community to copy, distribute, transmit or adapt the article content, providing a proper, prominent and unambiguous attribution to the authors in a manner that makes clear that the materials are being reused under permission of a Creative Commons License. Views, opinions and conclusions expressed in this research article are views, opinions and conclusions of the author(s). Open Access Publishing Group and European Journal of Education Studies shall not be responsible or answerable for any loss, damage or liability caused in relation to/arising out of conflicts of interest, copyright violations and inappropriate or inaccurate use of any kind content related or integrated into the research work. All the published works are meeting the Open Access Publishing requirements and can be freely accessed, shared, modified, distributed and used in educational, commercial and non-commercial purposes under a Creative Commons Attribution 4.0 International License (CC BY 4.0). 